\title{
Hvidbog om udvikling af universitetsundervisning
}

\author{
Sebastian Horst, specialkonsulent, Institut for Naturfagenes \\ Didaktik, Kфbenhavns Universitet.
}

I denne artikel præsenteres Hvidbog om udvikling af universitetsundervisning der udkom i juni 2011 som et resultat af DUN-konferencen 2011 arrangeret af Institut for Naturfagenes Didaktik på Københavns Universitet.

Hvorfor lave en konference med temaet undervisningsudvikling og hvorfor ligefrem en hvidbog? Det skyldes flere ting. For det første må undervisningsudvikling betragtes som det der helt centralt kendetegner god undervisning. Det er nødvendigt løbende at afstemme undervisningens indhold og form til de studerendes behov. Samtidig ændrer det omgivende samfunds krav til uddannelse sig, og også forskningens fremdrift giver anledning til løbende forandringer i en forskningsbaseret uddannelse. Derfor må undervisningen undergå samme dynamiske udvikling som alt andet på universitetet.

For det andet er det ret tydeligt at der de seneste år er kommet mere fokus på udvikling af undervisning og didaktiske/pædagogiske kompetencer på universiteterne: Der er flere steder indført krav om deltagelse i pædagogiske kurser (fx for ph.d.studerende), der er flere steder puljefinansierede initiativer til at igangsætte udvikling, og endelig begynder universiteternes ledelser også flere steder at tale om hvor vigtigt det er at sikre kvalitetsudvikling.

Men for det tredje oplever vi der stod bag konferencen og arbejdet med at lave hvidbogen, at betingelserne for at udvikle undervisning ikke bliver bedre - faktisk er der flere aspekter der trækker i retning af at gøre det sværere at udvikle undervisningen!

Denne lidt paradoksale situation gav anledning til konferencens - og hvidbogens undertitel: "Rammer, barrierer og muligheder". Den afspejler ønsket om at se undervisningsudvikling i et bredt perspektiv. Udvikling er afhængig af fx økonomiske og organisatoriske rammer og støder lejlighedsvis ind i barrierer - både reelle barrierer og dem som blot synes uovervindelige. Men en tydeliggørelse af rammer og barrierer kan åbne op for bedre muligheder for udvikling af danske universitetsuddannelser. 


\section{En hvidbog for at fastholde og sammenstille}

DUN-konferencens første dag handlede om at dele viden om undervisningsudvikling, mens andendagen fokuserede på, hvordan vi kan skabe bedre udvikling af universitetsundervisning $\mathrm{i}$ form af forskellige tiltag: Individuelle tiltag, institutionelle tiltag og nationale tiltag. Disse diskussioner skete ved slutningen af konferencen og dermed på baggrund af de foregående plenumoplæg og symposier (se programmet på hjemmesiden www.ind.ku.dk/dunk).

For at de mange diskussioner og forslag ikke skulle forsvinde, besluttede arrangørgruppen at forfatte en hvidbog umiddelbart i forlængelse af konferencen. Et første udkast blev udsendt til oplægsholdere og symposieansvarlige allerede dagen efter konferencen, og hvidbogen blev herefter skrevet færdig i løbet af halvanden uge. Den blev udsendt til konferencedeltagere og en række andre nøglepersoner som pdffil 15. juni.

Hvidbogen er efterfølgende udgivet i IND's skriftserie nr. 22/2011: "Udvikling af universitetsundervisning - rammer, barrierer og muligheder" og er tilgængelig på http://www.ind.ku.dk/skriftserie.

I det følgende gennemgås nogle af de vigtigste udfordringer mht. udvikling af universitetsundervisning der beskrives i hvidbogen, og herefter gives et kort sammendrag af hovedanbefalingerne til at skabe bedre undervisningsudvikling.

Efterfølgende har vi modtaget mange interessante tilkendegivelser på hvidbogen alle af positiv karakter. Det lader til at temaet, dilemmaerne og udfordringerne er noget som flere organisationer og institutioner har sat på dagsordenen i denne tid. Vi håber at hvidbogen fortsat kan være til inspiration og gavn inden for det universitetspædagogiske miljø hvor der arbejdes med at udvikle undervisning, og udenfor i det politiske miljø som sætter rammerne for undervisningsudviklingen - og har ansvaret for at disse rammer forbedres!

\section{Uddannelse er det primære samfundsmæssige afkast af universiteterne}

Det er nok rimeligt at sige at $\mathrm{i}$ hvert fald de ældste universiteter i Danmark har været noget fodslæbende i forhold til pædagogisk efteruddannelse af lærerne. Men dette har ændret sig. Universiteterne forsøger faktisk at gøre noget for at styrke undervisningen, og her står udviklingen af adjunktpædagogikum nok som den mest synlige satsning på universiteterne. Således har adjunktpædagogikum over en periode på 10-15 år udviklet sig til nu at være robust og naturligt forankret på mange universitetsfakulteter. 
Hvidbogen slår fast at som hovedregel har deltagerne i adjunktpædagogikum, både adjunkter og postdoc'er, det tilfælles at de enten er eller bliver oprigtigt optaget af undervisning. Deltagerne mener generelt at undervisning er vigtig, og at der er behov for en styrkelse af undervisningen på universiteterne. Og de vil det gerne. Men ofte hænger det ikke sammen med den situation som de er i, hvor incitamentsstrukturerne for at prioritere forskning er langt stærkere end for at prioritere undervisning, og hvor undervisning for fx post.doc.'er typisk kun udgør en lille del af deres arbejdsindhold. Der kan altså på grund af rammerne for universiteterne være klare grunde til at nedprioritere undervisningsudvikling. Denne situation skyldes både de grundlæggende rammer og manglende ledelsesmæssige indsatser.

På grund af det igangværende generationsskifte er adjunktpædagogikum også strategisk vigtig for universitetet. Når de unge forskere/undervisere får en pædagogisk uddannelse, er de med til at præge hvordan undervisning opfattes og praktiseres på institutterne på længere sigt.

Der er dog inden for de seneste år også taget andre initiativer til at styrke kvaliteten af undervisningen. De fleste af disse initiativer er for så vidt fornuftige nok. På et overordnet plan er de udtryk for at universiteterne efterhånden pålægges og påtager sig et ansvar for at underviserne får mulighed for at udvikle sig pædagogisk. Men mange oplever at der i for høj grad er tale om ukoordinerede tiltag og indsatser. Det er også karakteristisk at alle disse nye tiltag er øgede krav til dem der skal forestå undervisningen, samtidig med at kravet om at skaffe eksterne midler til forskning øges.

Hvidbogen argumenterer for at vi må se på selve fundamentet for universiteternes virke, dvs. hvordan midlerne bevilges, og hvordan underviserne ansættes. Det er afgørende at forstå at forskningspolitikken har implikationer for universitetsuddannelserne. Der er derfor brug for at politikerne tænker sammenhængende om universiteterne som steder for både forskning og uddannelse og forstår at ændringer i bevillingssystemet for forskningen har betydning for prioriteringen af undervisningen. Det er nødvendigt at der på det nationale niveau skabes et system som tilskynder til en balancering mellem universitetets tre formål (forskning, uddannelse, formidling/kontakt til det omgivende samfund). Og der er i dag tydelige tegn på at det ikke er muligt at opretholde en god balance på de lokale niveauer.

\section{Indsatser på flere niveauer}

På DUN-konferencen var der fire plenumoplæg til at give en ramme for diskussionerne. To af dem - Thomas Harboe og James Wisdom - er blevet til artikler i dette nummer af DUT, så de skal ikke omtales mere her. De to øvrige af henholdsvis Fre- 
derik Voetmann Christiansen fra Københavns Universitet og Stefan Lindgren fra Lunds Universitet pegede begge på nødvendigheden af indsatser på flere niveauer der trækker i samme retning. I sit oplæg argumenterede Frederik Voetmann Christiansen for at vi i en analytisk model kan se alle aktører i uddannelsesudviklingen fordelt på tre niveauer: Mikro-, meso- og makroniveauet.

Mikroniveauet, eller individniveauet, indbefatter de enkelte undervisere, studerende, de kursusansvarlige m.fl. og handler således om det der sker i den konkrete undervisning. Et eksempel på hvordan man forsøger at skabe undervisningsudvikling på dette niveau, er efteruddannelseskurser af undervisere. Egentlig ved vi kun lidt om effekten af sådanne indsatser. Vi ved at længere kurser har større effekt end korte kurser, men meget tyder på at holdningen i den kultur som underviserne kommer fra, er mere afgørende for om sådanne kurser sætter sig blivende spor i undervisningen, end hvordan efteruddannelseskurset er tilrettelagt. En indsats på mikroniveauet kan godt sætte sig spor hos den enkelte deltager, men skal der ændres i den lokale undervisningskultur, forudsætter det at der her er vilje og ressourcer til at imødekomme forandringerne. Og hermed bevæger vi os over på mesoniveauet som omfatter den sammenhæng som underviserne mv. indgår i.

Mesoniveauet kan have forskellig form: Det kan være et (mindre) institut, en afdeling eller en gruppe defineret på anden vis, fx som alle 1.-årsundervisere på en uddannelse. Dette niveau er særligt interessant da det i høj grad er i dette forum at balancen mellem forskning og undervisning præges. Det er muligvis også dette niveau som det kan være særlig svært at påvirke - både for de enkelte undervisere og for de lokale ledere i miljøet.

Det sidste og det overordnede niveau er makroniveauet som kan være et ledelsesteam, et universitet, et fakultet eller et stort institut. Indsatser fra makroniveauet har den risiko at de let kommer til at virke anderledes end ønsket. Et eksempel på dette er når kvalitetssikringsmekanismer (der måske nok er tænkt som fremmende for god undervisningspraksis) i undervisningsmiljøerne, dvs. mesoniveauet, bliver opfattet som kontrolforanstaltninger snarere end som ressourcer for kvalitetssikring. Dette er der eksempler på er sket med indførelsen af generelle, systematiske kursusevalueringer efter ønske fra ledelsesniveau. For at et sådant tiltag skal virke fremmende for kvaliteten af undervisningen, skal det både optages af den enkelte underviser og indgå i den fælles undervisningskultur som underviserne er en del af.

Det skal understreges at denne mikro-, meso- og makroopdeling er analytisk. I praksis er der flydende overgange mellem niveauerne, og indsatser på ét niveau vil alt andet lige påvirke de andre niveauer. Indsatser på ét niveau forudsætter ressourcer 
og udviklingsvillighed på de andre niveauer. For at skabe varige og forbedrende forandringer i uddannelserne skal indsatserne prioriteres på alle niveauer.

Stefan Lindgren fortalte i sit oplæg på konferencen at man på Lunds Universitet i projektet EQ11 forsøger at gøre op med tanken om at forskning på universiteter og undervisning på universiteter er to adskilte opgaver. Fra øverste ledelsesniveau og hele vejen gennem organisationen søger man en helt anden type følsomhed over for metode- og undervisningsudvikling. Man vil tænke anderledes om den måde arbejdet værdisættes på. Det handler om at arbejde bedre, ikke om at undervise eller forske bedre. En sådan etablering af den universitetsansattes position gør det svært for alle parter at stille spørgsmål ved hvorvidt undervisningsudvikling er for bekostelig og tidskrævende.

Et væsentligt element i dette skifte er en insisteren på et fuldstændigt medejerskab blandt universitets ansatte i formuleringen af en klar og tydelig målsætning om kvalitetsudviklingsprojekternes retning. Således er der vedtaget en definition af forskningsbaseret undervisning der prioriterer et syn på forskning som en proces der foregår, og undervisning der inkluderer de studerende som deltagere. Herfra er der ikke langt til tanken om en forsknings-undervisningsintegration, hvor de studerende bliver betragtet som deltagere i forskningsprocessen.

\section{Mere fokus på fællesskabers undervisningskulturer}

Ifølge hvidbogen skal der især sættes fokus på mesoniveauet - dvs. hvordan man styrker et fællesskab omkring det at undervise forskningsbaseret. Mange nye VIPansatte i Danmark indgår først og fremmest i forskningsfællesskaber. Der er behov for et system hvor det er lige så naturligt for en VIP at indgå i et stærkt og udviklende undervisningsfællesskab. Dette kræver måske nok indsatser fra makroniveauet lige som det selvfølgelig også fordrer en interesse fra mikroniveauet - men der er først og fremmest behov for at fokusere på hvordan vi på mesoniveauet kan skabe undervisningskulturer der understøtter udvikling af undervisning.

Som eksempel beskriver hvidbogen hvad man får af svar når man spørger deltagerne på adjunktpædagogikum ved det Naturvidenskabelige Fakultet på Københavns Universitet om de føler sig som forskere der underviser, eller som undervisere der forsker. Svaret er entydigt: At være ansat som adjunkt eller postdoc er at være ansat som forsker. Det upåagtet at adjunkters og for den sags skyld også lektorers tid som oftest er ligeligt fordelt mellem forskningsopgaver og undervisningsopgaver. Adjunkterne forklarer og begrunder selv den holdning til forskeridentiteten med henvisning til den incitamentsstruktur der er etableret for at sikre en høj forskningsaktivitet. I de mange situationer der opstår hvor man skal prioritere undervisning mod 
forskning, oplever de unge VIP'er ikke at der reelt findes et valg. De bliver nødt til at prioritere forskningsansøgninger og ligeledes den forskningsmæssige grundighed der er forudsætningen for at ansøgningerne løbende bevilges. Således opleves spørgsmålet om undervisningsudvikling ikke som udtryk for manglende vilje men simpelthen som udryk for en organisering på universitetet og i bevillingsstrukturen der udelukkende peger på forskning og på en nedprioritering af undervisningsindsatsen.

\section{Sammendrag af anbefalinger}

\section{Fndring af bevillingssystem til universiteterne}

Der bør udformes et bevillingssystem som giver incitamenter til prioritering af udvikling af universitetsundervisning. En større andel af midlerne til universiteterne ønskes fordelt som basismidler for at sikre muligheder for at skabe undervisningsudvikling. Folketinget bør sikre at forskningsmidler kommer uddannelsesindsatsen til gavn. Det kan ske ved at forskningsbevillinger kobles til uddannelsesaktiviteter.

\section{Publicering af artikler om undervisningsudvikling}

Peer review'ede artikler om undervisning og udvikling heraf bør være lige så meriterende som forskningsartikler.

\section{Udvidelse af taxametersystemet}

Taxametersystemet ønskes udbygget med en andel til finansiering af undervisningsudvikling og evaluering. Pengene skal gives på universitetsniveau, så det er muligt at prioritere på årsbasis.

\section{Andring af stillingsstrukturer for universitetsansatte}

Det ønskes at der i alle stillinger stilles krav til udvikling af undervisningskompetencer. Således bør også postdoc-ansættelser indebære undervisning.

\section{Samarbejde mellem de danske universiteter om en national kompetence-} udviklingsstrategi

De danske universiteter bør samarbejde om udvikling af undervisning, og der ønskes incitamenter hertil fra centralt hold i form af en national kompetenceudviklingsstrategi for universitetsundervisere. Strategien kan udarbejdes i et samarbejde under Danske Universiteter med inddragelse af relevante organisationer, fx DM, DJØF, DSR og DUN. 


\section{Pulje til særlige indsatser for undervisningsudvikling}

Videnskabsministeriet bør oprette en centralt administreret pulje til særlige udviklingsindsatser inden for undervisning.

\section{Centers of excellence}

Der bør oprettes en række "centers of excellence" inden for uddannelsesudvikling således at specialkompetencerne på tværs af universiteterne kan udnyttes.

\section{Tydelige krav og mål for undervisningsområdet fra ledelsesniveau}

Der skal fra ledelsen på alle niveauer, lige fra studieleder, institutleder, dekan og til rektor, være klare mål for institutters/uddannelsers indsats på undervisningsområdet.

\section{Bedre brug af undervisningsportfolio}

De danske universiteter bør i fællesskab udrede hvilke krav der er til undervisningsportfolioer samt hvilke behov de skal opfylde.

\section{Undervisningsudvikling som del af MUS}

Undervisning og udvikling heraf skal indgå som fast element i medarbejderudviklingssamtaler.

\section{Kompetenceudvikling af fastansat videnskabeligt personale}

Der skal lokalt opstilles målsætninger for pædagogisk kompetenceudvikling til fastansatte VIP (lektorer og professorer). Det er oplagt at gøre dette funktionsafhængigt, dvs. at ny funktion og rolle som underviser ledsages af kompetenceudvikling. En incitamentsstruktur i form af løntillæg bør også indtænkes.

\section{Styrkelse af undervisningsfællesskaber}

Den lokale ledelse af undervisningen (kursusansvarlige, studieledelse, institutledelse) skal etablere og understøtte gensidigt forpligtende undervisningsfællesskaber.

\section{Pædagogisk opkvalificering af ledere}

Universitetsansatte med ledelsesopgaver bør besidde pædagogisk indsigt og kompetence. 


\section{Lokale ressourcer og redskaber til at udvikle undervisning}

Den lokale studie- og undervisningsleder skal råde over og anvende ressourcer og redskaber som giver mulighed for at gennemføre udviklingsopgaver. Ledelsen skal medvirke til at god undervisning og undervisningsudvikling bliver anerkendt og synliggjort på lige fod med forskningen, og det kræver både holdnings- og handlingsorienterede tiltag.

\section{Studenterinddragelse i undervisningsudvikling}

Studerende bør som udgangspunkt altid inddrages i undervisningsudvikling.

\section{Langsigtet organisering af den universitetspædagogiske indsats}

Det enkelte universitet skal sørge for en organisering af universitetspædagogiske enheder der sikrer forskningsbasering og en sammenhængende indsats både over tid og på tværs af faglige miljøer.

Sebastian Horst arbejder som projektmanager og specialkonsulent på Institut for Naturfagenes Didaktik, Københavns Universitet. Han var tovholder for planlægningen og afholdelsen af DUN-konferencen $2011 \mathrm{og}$ produktionen af hvidbogen. Til daglig arbejder han med udvikling og evaluering af undervisning og uddannelser, byggeri og indretning af undervisningsfaciliteter. Han varetager også overordnet projektstyring af instituttets projektportefølje og er redaktør af tidsskriftet MONA. 